\title{
Bivalves from Cretaceous cold-seep deposits on Hokkaido, Japan
}

\author{
Steffen Kiel, Kazutaka Amano, and Robert G. Jenkins \\ Acta Palaeontologica Polonica 53 (3), 2008: 525-537 doi:http://dx.doi.org/10.4202/app.2008.0310
}

Cretaceous cold-seep deposits of the Yezo Group on Hokkaido, Japan, yield a rich and well-preserved mollusk fauna. The systematics of nine bivalve species previously reported from these deposits can now be reevaluated using newly collected fossils. The fossils include a Cenomanian specimen of Nucinella gigantea with a drill hole possibly made by a naticid, by far the oldest record of a drill hole from a cold seep site. In Japan, Cretaceous seep bivalve assemblages are characterized by (i) the unique occurrence of large specimens of Nucinella (Manzanellidae), (ii) the commonly present nuculid Acila (Truncacila), and (iii) a high diversity of lucinids, possibly as many as four distinct genera. Two new species described are the Albian Acharax mikasaensis (Solemyidae) and the Albian to Campanian Thyasira tanabei (Thyasiridae), of which the former had previously been misidentified as the oldest vesicomyid, the latter as the oldest Conchocele.

Key words: Solemyidae, Manzanellidae, Lucinidae, Thyasiridae, hydrocarbon seeps, chemosymbiosis, Cretaceous, Japan

Steffen Kiel [steffen.kiel@gmx.de], Institut für Geowissenschaften, Christian-Albrechts-Universität Kiel, Ludewig-Meyn-Str. 10, 24118 Kiel, Germany, and Dept. of Paleobiology, Smithsonian Natural History Museum, Box 37012, Washington DC 20013-7012, USA; Kazutaka Amano [amano@ juen.ac.jp], Department of Geoscience, Joetsu University of Education, Joetsu 943-8512, Japan; Robert G. Jenkins [robertgj@ynu.ac.jp], Faculty of Education and Human Sciences, Yokohama National University, Kanagawa 240-8501, Japan.

This is an open-access article distributed under the terms of the Creative Commons Attribution License (for details please see creativecommons.org), which permits unrestricted use, distribution, and reproduction in any medium, provided the original author and source are credited. 
Fof Full text $(970.4 \mathrm{kB})$ 